\section{CarakaTani \\ Journal of Sustainable Agriculture \\ ISSN 2613-9456 (Print) 2599-2570 (Online)}

\title{
Analysis of Marketing Opportunity Increase based on Consumer Criteria for Hydroponic Vegetable Producers in Surabaya
}

\author{
Titik Yuliarini' ${ }^{1}$, Soeharsono ${ }^{2}$, Mirni Lamid ${ }^{3}$, Mohammad Anam Al Arif ${ }^{3}$, Sarmanu$^{2}$ and Sri Hidanah ${ }^{3 *}$ \\ ${ }^{1}$ Department of Veterinary Agribusiness, Faculty of Veterinary Medicine, Universitas Airlangga, \\ Surabaya, Indonesia; ${ }^{2}$ Department of Veterinary Anatomy, Faculty of Veterinary Medicine, \\ Universitas Airlangga, Surabaya, Indonesia; ${ }^{3}$ Department of Animal Husbandry Science, \\ Faculty of Veterinary Medicine, Universitas Airlangga, Surabaya, Indonesia
}

*Corresponding author: sri-h@fkh.unair.ac.id

\begin{abstract}
Consumer is one of the influential factors in marketing. The study was conducted to analyze the increase in marketing opportunities based on consumer criteria for hydroponic vegetable producers in Surabaya. The research was carried out in Surabaya from Mei to June 2018. This type of research is observational analysis with survey methods on three producers about the relationship between producers and consumers according to their respective producers. Data were analyzed with AHP (Analysis Hierarchy Process) and the process used Expert Choice 2000. Data were examined using descriptive or qualitative analysis and quantitative analysis. Quantitative analysis includes a scale of trust and commitment measurement. The distribution of hydroponics vegetables at "Kebunsayur Surabaya" prioritizes 'restaurant' and 'hotel', "JawaRa Farm" prioritizes 'kale suppliers' and "One STOP Hydroponics" prioritizes 'individual customers' (vegetable displays).
\end{abstract}

Keywords: AHP; consumer preferences; marketing plan; marketing strategy

Cite this as: Yuliarini, T., Soeharsono, Lamid, M., Al Arif, M. A., Sarmanu, \& Hidanah, S. (2020). Analysis of Marketing Opportunity Increase based on Consumer Criteria for Hydroponic Vegetable Producers in Surabaya. Caraka Tani: Journal of Sustainable Agriculture, 35(2), 278-288. doi: http://dx.doi.org/10.20961/ carakatani.v35i2.29622

\section{INTRODUCTION}

Vegetable production is an essential sector in global agribusiness, especially for Indonesia's economy and development, because it has the ability to increase agricultural productivity compared to cereals and other staple crops (Johnson et al., 2008). Vegetable production in Indonesia has experienced a significant growth, yet has a relatively low share of the global vegetable industry. Improvements in agricultural practices, availability of several crop varieties and improved irrigation infrastructure are some of the reasons for increasing vegetable production that has recently been observed (Mariyono, 2019).
Vegetable cultivation must be carried out to meet the increasing market needs. Vegetable cultivation systems with hydroponic techniques are solutions to the challenges of urban farmers. Hydroponics is a technology for growing plants in nutrients solutions with or without the use of artificial medium to provide mechanical support (Kumar and Cho, 2014). Hydroponic system can produce higher quality vegetable products continuously compared to conventional agriculture. In the context of sustainable agriculture, hydroponics is an attractive resource in terms of saving water and fertilizer, which is becoming increasingly relevant especially in the countries with a lack of rain or inadequate quality

\footnotetext{
* Received for publication April 22, 2019

Accepted after corrections April 3, 2020
} 
water and limited ability of farmers to afford the costs of buying large quantities of fertilizer (Sambo et al., 2019). Hydroponic vegetable production in "Kebunsayur Surabaya", "JawaRa Farm" and "One STOP Hydroponics" is 100\% free of pesticides. This system at least minimizes chemicals that are polluting the environment.

Hydroponic vegetable producers tend to cultivate hydroponic vegetables by considering market opportunities. "Kebunsayur Surabaya" cultivates Western vegetable products that include green oak lettuce, green leaf lettuce, red leaf lettuce, red oak lettuce and romaine and oriental vegetable product of water spinach. "JawaRa Farm" only produces oriental vegetables, such as red spinach, green spinach, batik spinach, bok choy and water spinach. "One STOP Hydroponics" grows Western hydroponic vegetables including green oak leaf and green romaine and oriental vegetables, such as red spinach, green spinach and water spinach.

Marketing in the agricultural sector is carried out to increase production. It has an effective policy to improve producers' income and consumers' purchasing power, especially on food products. Right decision for producers to sell their products is to manage an effort to increase their income. Purchase decision making of consumer is the decision making process and physical activity an individual engages in when evaluating, acquiring, using or disposing goods and services (Khuong and Duyen, 2016). Therefore, this is a process of purchasing one of several alternative solutions to problems with a real follow-up. After that, consumers evaluate their choices and then determine their next attitude.

In making decision, consumers play the roles of the initiators, influencers, deciders, buyers and users (Harahap, 2015). Producers should recognize these roles since they affect the process in designing products, determining messages and allocating promotional budget costs and creating a marketing program that suits the buyer (Swasta dan Handoko, 2000). The number is determined by the price, location and completeness. Consumers will pay attention to quality attributes or instructions in buying vegetables, especially hydroponic vegetables. Information about consumers' preferences is needed to determine consumers' desire (Yasmin et al., 2017), assuming that more information will be favored by consumers (Seo et al., 2019). Their desires and needs can be available with their preferences. Consumer behavior is the study of the processes involved when people choose, buy, use, or discard a product, service, idea or experience to satisfy their needs and desires. Consumer behavior denotes as a process that includes problems effecting consumers before, during and after purchase (de Mooij, 2019). This study aims to analyze the increase in marketing opportunities based on the criteria of consumer criteria for hydroponic vegetable producers in Surabaya.

\section{MATERIALS AND METHOD}

This research was conducted in Surabaya from May to June 2018. The respondents in this study were hydroponic vegetable producers in "Kebunsayur Surabaya", "JawaRa Farm" and "One STOP Hydroponics", located in Surabaya. In collecting data, questionnaires, interviews and documentation techniques were implemented. The research instruments were questionnaires, cameras, notebooks, stationeries and tape recorders and other recording devices.

This research included observational analysis using a survey on three producers about the relationship between producers and consumers according to their respective producers. The level of all producers, "Kebunsayur Surabaya", "JawaRa Farm" and "One STOP Hydroponics", is above the average. These criteria were identified by purposive sampling. The data were analyzed with AHP (Analysis Hierarchy Process) and processed using Expert Choice 2000. The analytic hierarchy process is a decision-making analysis technique that helps hydroponic vegetables producers to choose the distribution of hydroponic vegetables. The data analysis in the study utilized a scale of trust and commitment measurement (Morgan and Hunt, 2012). The data used were the primary data collected through by observations and interviews. The conceptual framework is explained in Figure 1. The hierarchical structure concepts of research on "Kebunsayur Surabaya", "JawaRa Farm", "One STOP Hydroponics" are successively presented in the Figure 2, Figure 3 and Figure 4. 


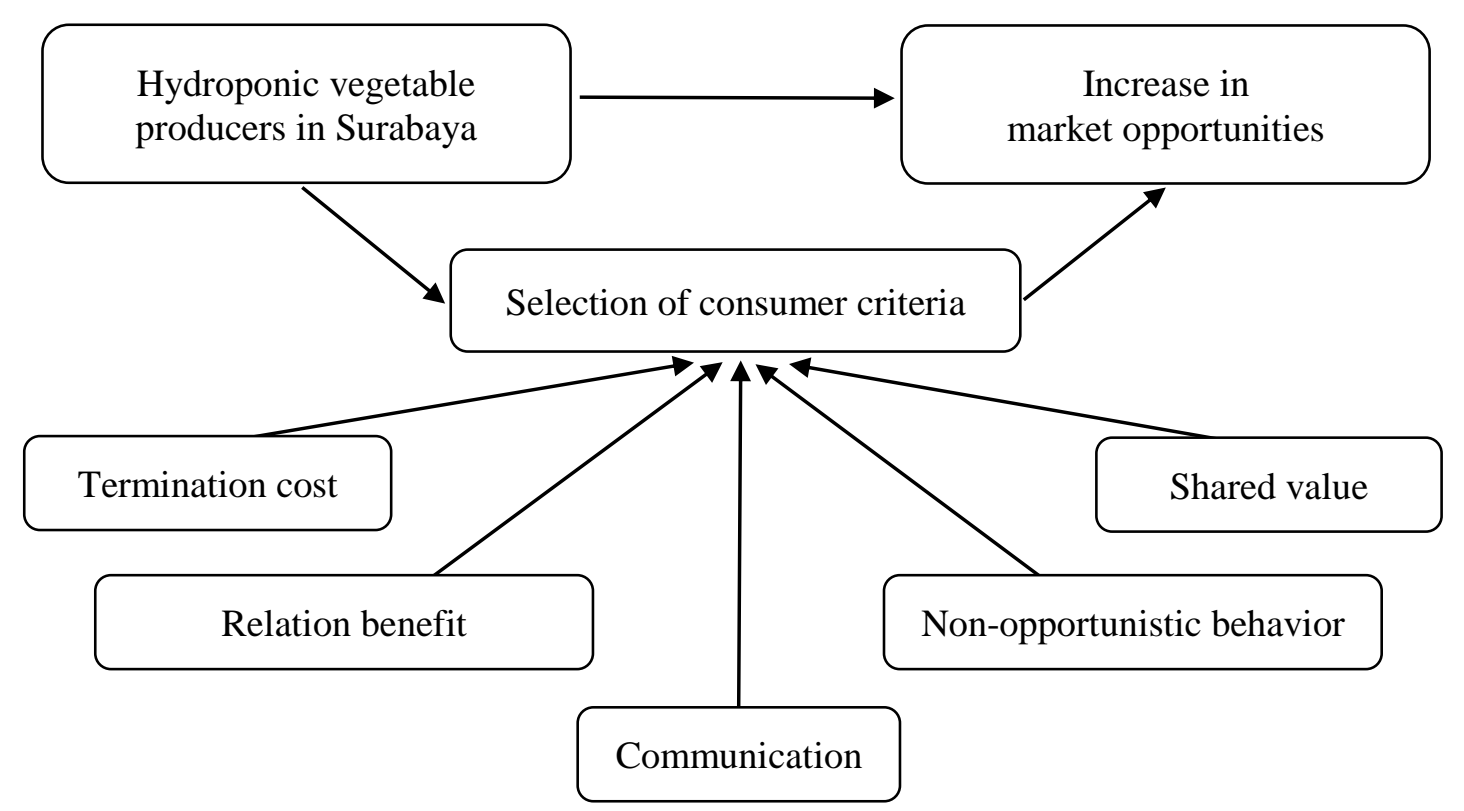

Figure 1. Conceptual framework of this research

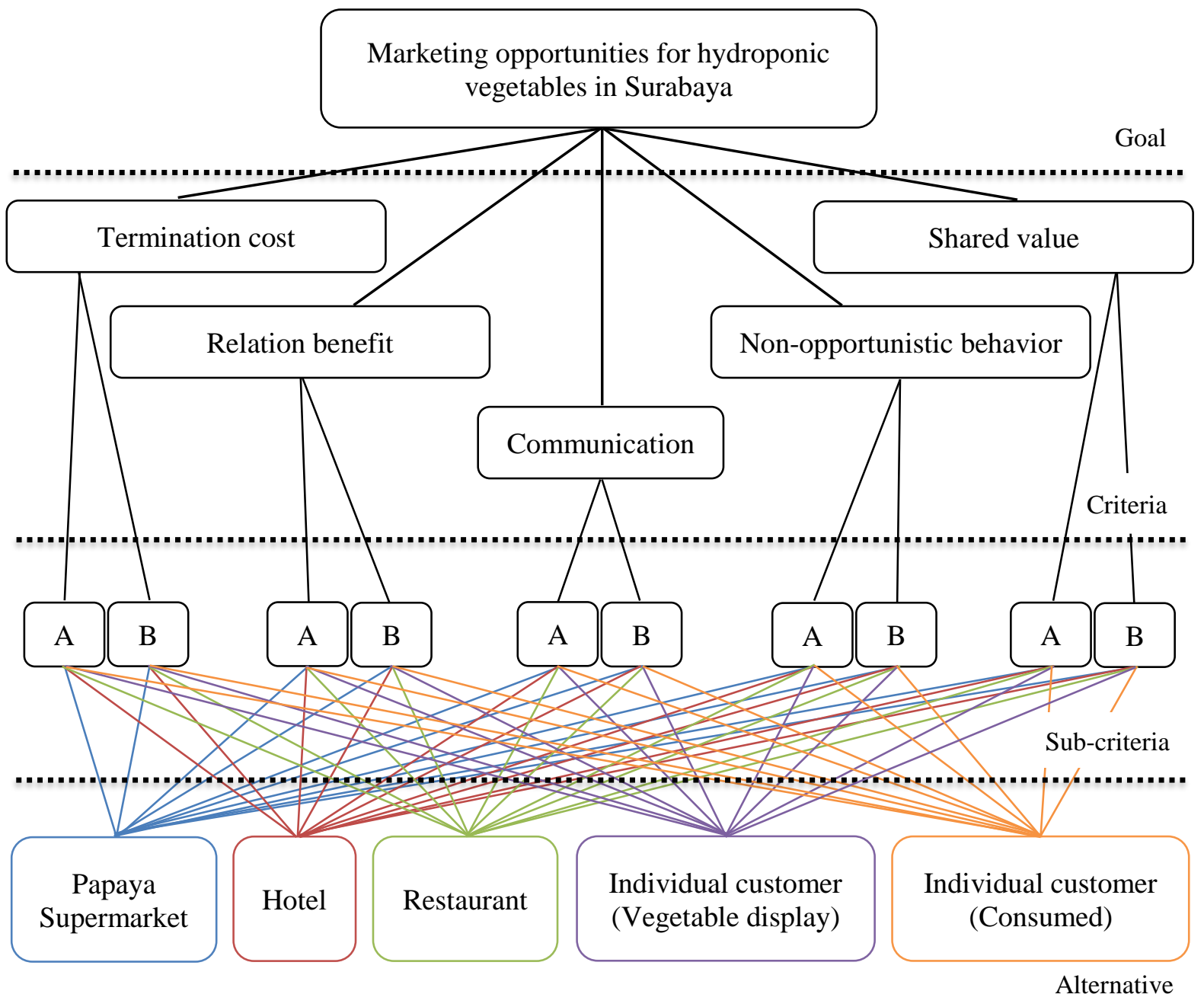

Figure 2. The hierarchical structure concept of the research on "Kebunsayur Surabaya" 
Note:

Criteria : A chart was utilized to reach the decision-making goal of the hydroponic vegetable marketing channel based on five priority elements, namely: termination cost, benefit relations, shared value, communication and non-opportunistic behavior assessed by a paired comparison scale in Figure 2

Sub-criteria : The chart was used to select the priority of choices (A or B) in the sub-criteria of the five criteria factors. Termination cost A: prospective customer; B: product fulfillment standard; relation benefit A: benefit, B: satisfaction and comfort; shared value A: fair benefit share, B: no or rare complaints; communication A: trading information B: open communication; non-opportunistic behavior A: benefit-giving agreement, B: long-term relationship in Figure 2

Alternatives : The chart was used to select priorities from five alternatives, namely: 'papaya supermarket', 'hotels', 'restaurants', 'individual customers' (vegetable displays), 'individual customers' (consumed) in Figure 2

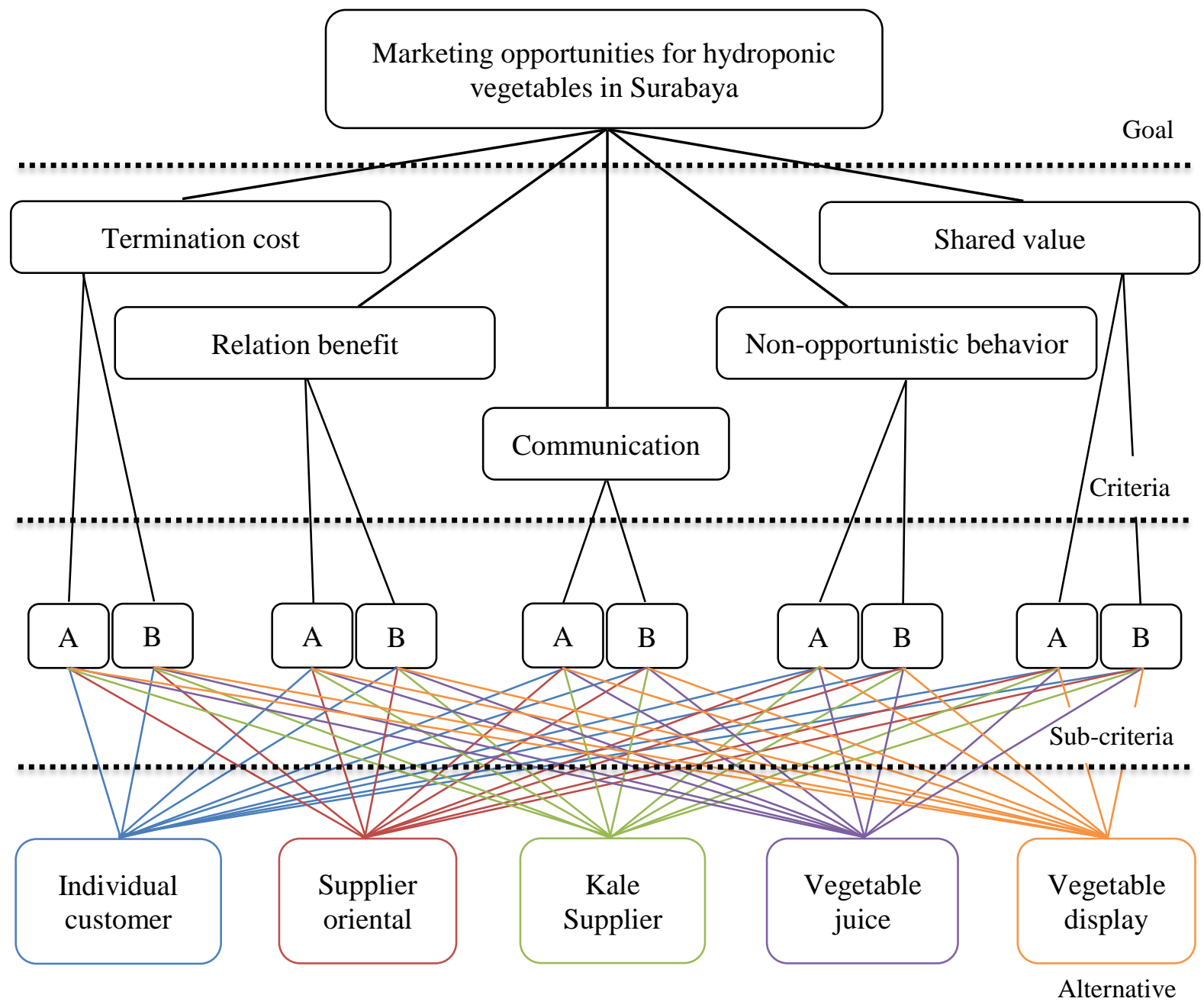

Figure 3. The hierarchical structure concept of the research on "JawaRa Farm"

Note:

Criteria : The chart was used to reach the decision-making goal of the hydroponic vegetable marketing channel based on five priority elements, namely: termination cost, benefit relations, shared value, communication and non-opportunistic behavior assessed by a paired comparison scale in Figure 3 
Sub-criteria : The chart was applied to select the priority of choices (A or B) in the sub-criteria of the five criteria factors. Termination cost A: prospective customer; $\mathrm{B}$ : product fulfillment standard; relation benefit A: benefit, B: satisfaction and comfort; shared value $\mathrm{A}$ : fair benefit share, $\mathrm{B}$ : no or rare complaints; communication $\mathrm{A}$ : trading information B: open communication; non-opportunistic behavior A: benefit-giving agreement, B: long-term relationship in Figure 3

Alternatives : The chart was utilized to select priorities from five alternatives, namely: 'individual customers', 'oriental vegetable suppliers', 'kale suppliers', 'vegetable juices' and 'vegetable displays' in Figure 3

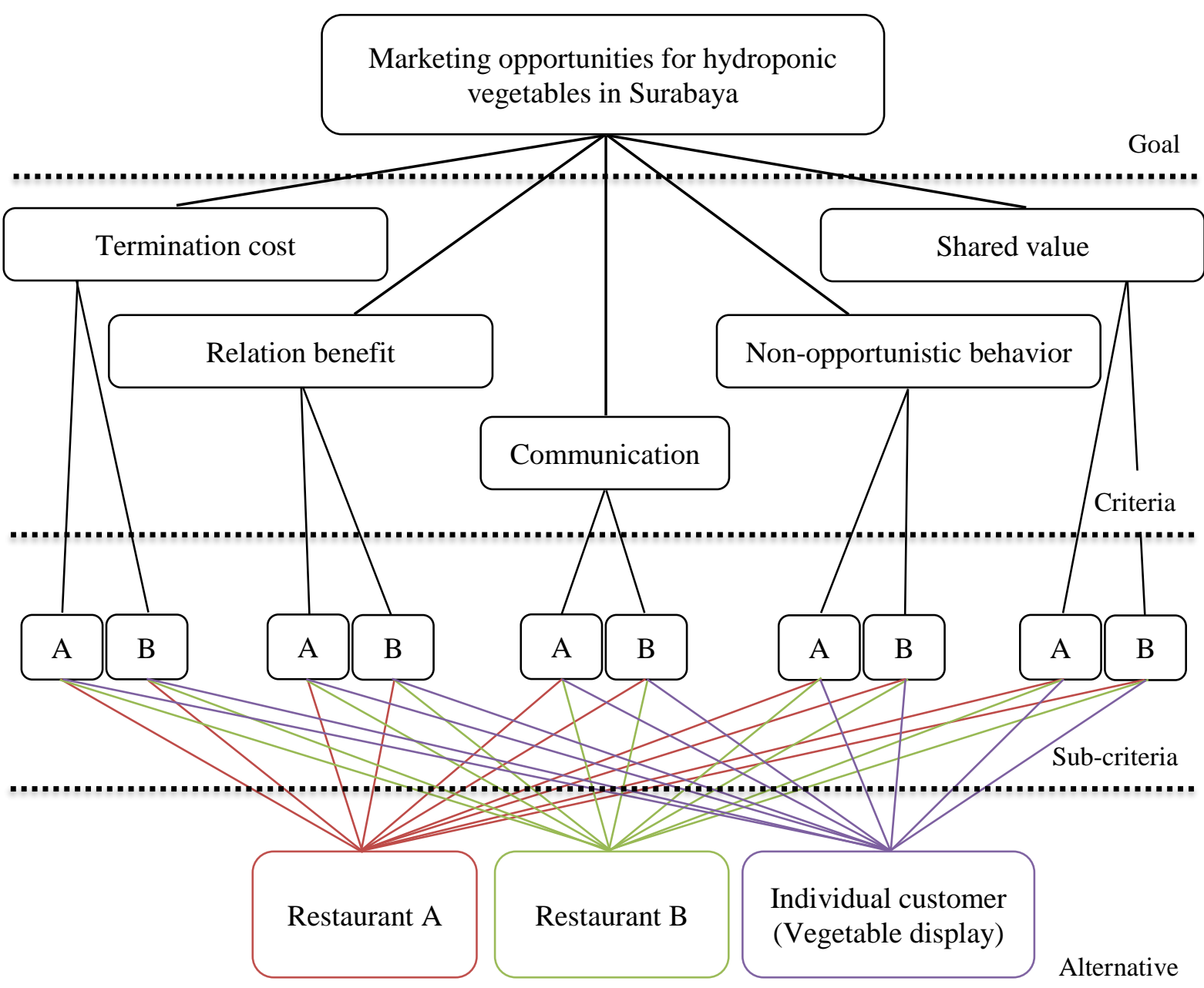

Figure 4. The hierarchical structure concept of the research on "One STOP Hydroponics"

Note:

Criteria : The chart was used to reach the decision-making goal of the hydroponic vegetable marketing channel based on five priority elements, namely: termination cost, benefit relations, shared value, communication and non-opportunistic behavior assessed by a paired comparison scale in Figure 4

Sub-criteria : The chart was employed to select the priority of choices (A or B) in the sub-criteria of the five criteria factors. Termination cost A: prospective customer; $\mathrm{B}$ : product fulfillment standard; relation benefit A: benefit, B: satisfaction and comfort; shared value A: fair benefit share, B: no or rare complaints; Communication A: trading information B: open communication; non-opportunistic behavior A: benefit-giving agreement, B: long-term relationship in Figure 4 
Alternatives : The charts was used to select priorities from three alternatives, namely: 'Restaurant A', 'Restaurant B' and 'individual customers (vegetable displays)' in Figure 4

\section{RESULTS AND DISCUSSION}

The highest priority aspect in the criteria is the termination cost of the second producer, "JawaRa Farm" with a value of $0.212 \%$ as presented in Figure 5. The main factor causing "JawaRa Farm" high termination cost is the customers of "JawaRa Farm" who are very prospective, meaning that they do not intend to disconnect the relationship or look for other customers. Besides, "JawaRa Farm" always endeavors to maintain a good buying and selling relationship. The producer has the ability to provide the best prices and quality products to customers or suppliers. This is related to the statement that a marketing relationship is defined by emphasizing social ties, cooperation and joint problem solving, sharing resources and activities and building a relationship based on shared goals (Ismail, 2009; Aziz and Noor, 2013). The nature of supplier-buyer relations can be explained in three relationship constructs, namely satisfaction, trust and commitment (Dwyer et al., 1987; Batt, 2000; Batt and Wilson, 2001; Hartmann et al., 2010; Schulze et al., 2014; Aji, 2016). The lowest value held in "JawaRa Farm" is a shared value due to the lack of satisfying customers. Efforts need to be made to improve customer satisfaction, namely commitment in the company to learn the strategies for providing customer needs and service quality to create a close relationship with customers (Jiwa, 2018).

The second highest priorities are shared value and non-opportunistic behavior of the third producer, "One STOP Hydroponics", with the same value of $0.210 \%$, as presented in Figure 5 . "Jawara Farm" and its customers have a selfless relationship and this contributes to excellent nonopportunistic aspect, for example, the ability to provide the best prices and quality products to customers or suppliers. This in accordance with Aziz and Noor (2013) who have stated that a positive relationship between transfer cost and relationship quality might indicate the fact that due to the high level of dependency on existing suppliers, retailers do not take coercive steps to ensure that the relationship fully functions with better quality. Shared value has the secondhighest value because corporate social responsibility refers to all relationships that occur between a company and its stakeholders, owners, or investors, government, suppliers to competitors, which is the accordance with the research of Rudiyanto et al. (2018).

The third-highest priority is the termination cost of the first producer, "Kebunsayur Surabaya", with a value of $0.205 \%$ as illustrated in Figure 5. The producer has a good continuous supply capability.

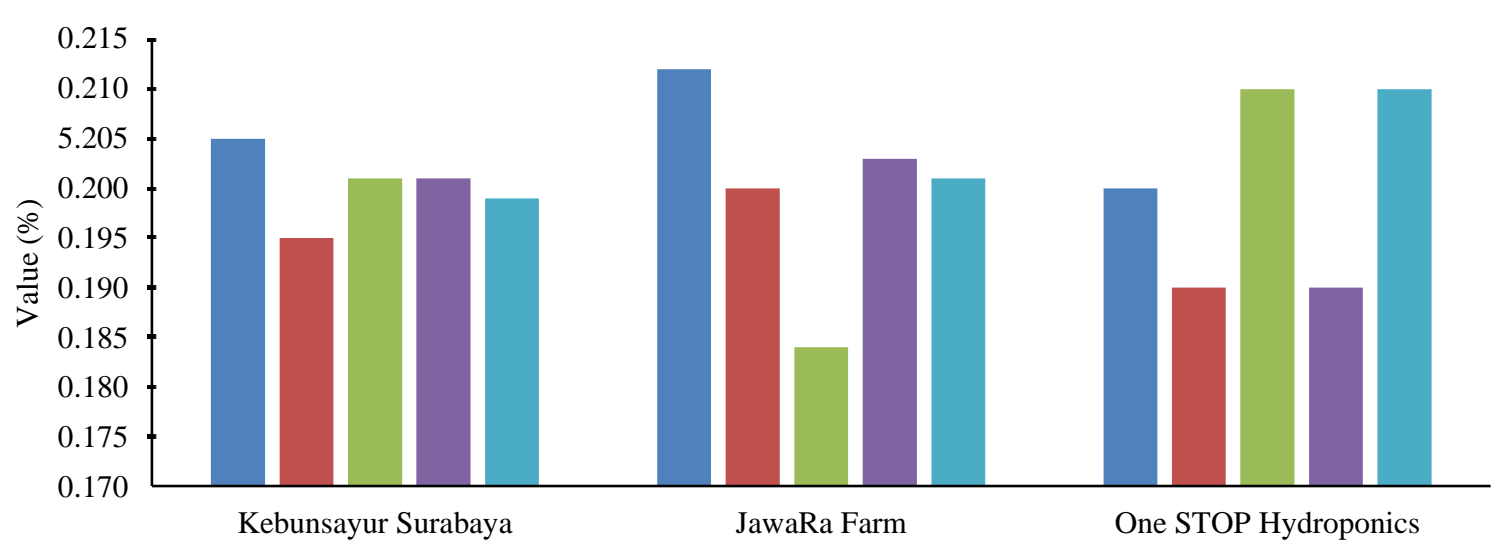

$\square$ Termination cost $\square$ Relation benefit $\square$ Share value $\square$ Communication $\square$ Non-opportunistic behavior

Figure 5. The criteria of three producers

The highest priority in the sub-criteria aspect is prospective customer, which is a part of the communication aspects and this is in line with
Sivanandamoorthy (2012) and Jiwa (2018) who have confirmed that customers always want an effective communication with the company. 
Good communication can certainly increase customers' confidence in the company. Communication also increases interest in longterm relationships with consumers, builds company image and creates loyalty (Levy et al., 2013). In the aspect of relation benefit, the third producer, One STOP Hydroponics, appears to have the same benefit value of $0.548 \%$ as summarized in Figure 6. The second-highest priority is the open communication of the second producer, "JawaRa Farm", with a value of $0.537 \%$, as demonstrated in Figure 6. "JawaRa Farm" has the power in exchanging valuable information. The trust relationship is an advantageous asset for a company (Masuku and Kirsten, 2004), which arises from the constant and detailed exchange of information or recurring relational relationships between trading parties (Hartmann et al., 2010). This reflects the extent to which trading partners view other parties as honest partners (Roberts-Lombard, 2017). The third-highest priority is a sub-criteria of share value, which is a fair benefit share to "JawaRa Farm", with a value of $0.535 \%$ as shown in Figure 6. "JawaRa Farm" has the ability to supply products in good condition and on time.

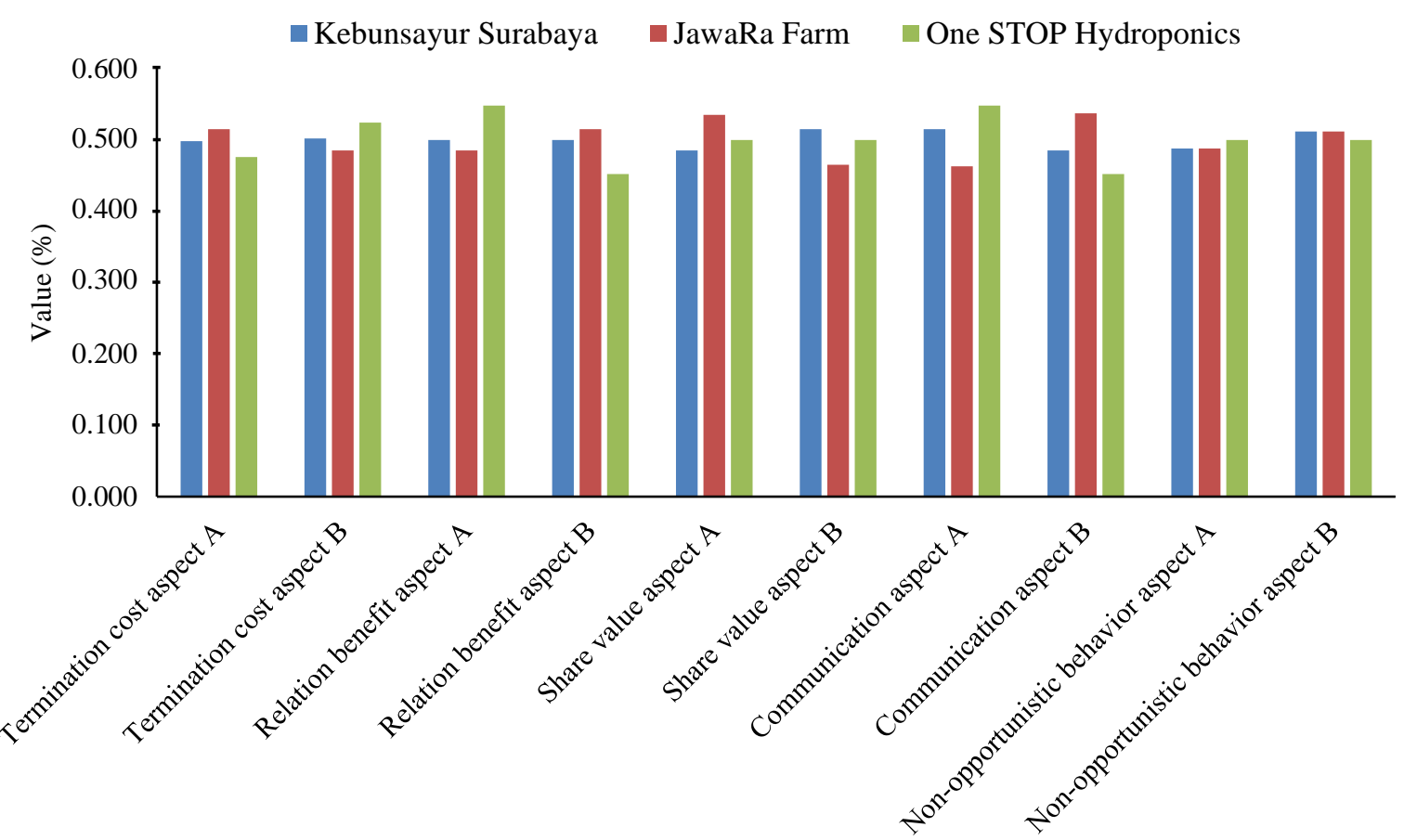

Figure 6 . The sub-criteria of three producers

The alternative of profitable marketing channels is determined according to the calculation using AHP method. The highest priority in alternative aspect is the individual customers' (displays) of "One STOP Hydroponics" with a value of $0.338 \%$ as demonstrated in Figure 7. The 'individual customers' (display) of sales counts to planting so it is very profitable to the producer. The secondhighest priority value is 'restaurant', an alternative for "One STOP Hydroponics", represented with a value of $0.331 \%$, as seen in Figure 7. 'Restaurant' needs continuous supply capability so as to provide benefits for the producer. The next priority is 'kale supplier', an alternative for "JawaRa Farm", with a value of $0.242 \%$ in Figure 7. Kale is highly profitable for the producer due to its high price.

"Kebunsayur Surabaya" is a strong internal organization. The influential internal factor is their location of the plantation, which is close to the consumer (Syaifullah and Syairudin, 2016). The location of the plantation determines the freshness of vegetables. The results of the study have indicated that the respondents favor hydroponic vegetables with a freshness level $<3$ days (Febrianti et al., 2019). The distribution of hydroponic vegetables in "Kebunsayur Surabaya" prioritizes 'restaurants' as the consumers. Supermarkets play an important role in linking 
farmers to markets through direct procurement while improving cultivation practice and participating in improving farmers' product quality (Srimanee and Routray, 2012). The number of large traders who are involved as intermediaries in the marketing process shows a long marketing channel. The shorter the marketing channel is, the greater the profit will be, compared to the long marketing channel (Ulfa and Masyhuri, 2019). Marketing costs will be greater than the product result in a long marketing channel. This kind of situation causes inefficient marketing channels that can provide a fair price for farmers as producers and in the end will greatly influences more productive farmers (Mawardati, 2018).

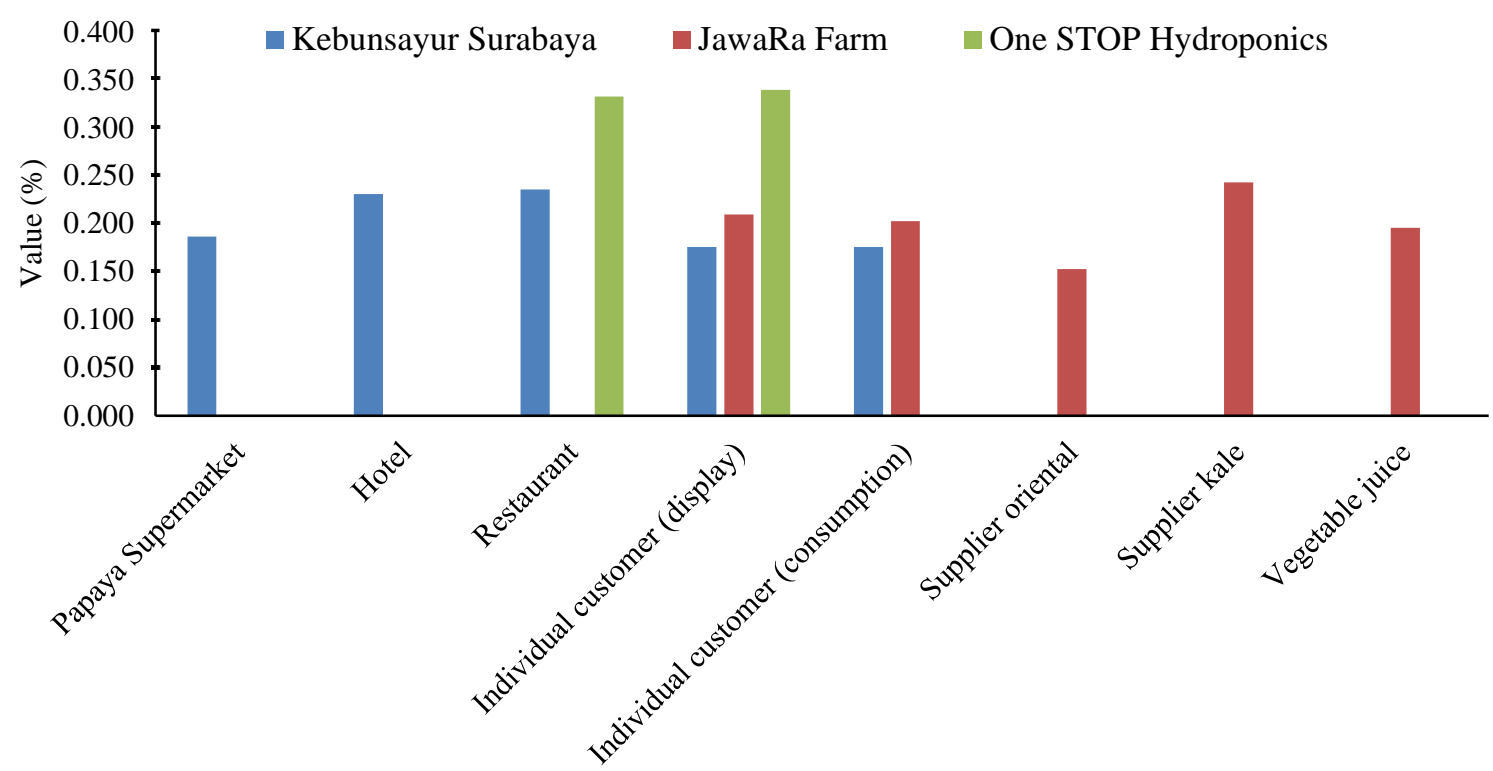

Figure 7. The marketing channel alternatives of three producers

"JawaRa Farm" prioritizes 'kale suppliers' because kale is more rewarding for the producer due to its high price. Suppliers of oriental vegetables are at the lowest position since the offered prices are very low and all types of vegetables are valued the same. The average consumers are also unable to distinguish better quality hydroponic vegetables, so they are more likely to request the same price for all vegetables, especially by considering that oriental vegetables can be found in traditional markets. Demand and supply conditions are closely related to price elasticity, the presence of substitute goods, market growth, types of goods, technology, raw materials, economies of scale and others (Abubakar et al., 2017). The producers are farmers with weak components in determining prices for shipping goods to consumers. Dependence of producers on suppliers also results in high losses if they cannot set an adequate price with following the production cost. Decision making in selecting vegetable distribution must be carefully considered for the benefit of producers. This is also to minimize the form of marketing channels that will affect the costs, profit and marketing efficiency (Erzal et al., 2016).

"One STOP Hydroponics" prioritize focuses on 'individual customers' (vegetable displays) because the prices are commonly calculated per stem. Hence, the price is relatively high and this is profitable for the producer. The lowest priority is given to 'Restaurant A' and 'Restaurant B', with the same value that is not much different from the value of vegetable display. "One STOP Hydroponics" does not choose many distribution locations, vegetable display and vegetable marketing because it only produces few hydroponic vegetables. There are only three locations for hydroponic vegetable distribution, namely 'Restaurant A', 'Restaurant B' and 'individual customers' who need vegetable displays.

An analytic hierarchy process is a basic approach to decision making. In this process, decision-makers use pairwise comparisons, which are utilized to discover alternative priorities (Ulfah, 2017). The concept of analytic hierarchy process is to change qualitative values into 
quantitative values, so the chosen decision can be more objective (Oelviani, 2013). The process of hierarchical analysis method provides an overview of some suitable places to continue the partnership. However, this depends on the decisions of each hydroponic vegetable producer. Business owners need to carry strategic management consisting of analyses, decisions and actions to create and maintain a competitive advantage (Widyastuti, 2017).

Increased selection of hydroponics vegetable distribution is expected to be conducted by each producer so that they can achieve better profit in accordance with the cost of producing hydroponic vegetables. In addition, the use of analytic hierarchy process is needed to read marketing business opportunities for improving balance in production. This analysis has been used by previous researchers at "Kebunsayur Surabaya" to develop their business. Previous researchers have concluded the similar point to develop hydroponic vegetable processed products and then maintain existing potential markets (Syaifullah and Syairudin, 2016). An effective marketing policy will encourage purchasing power, especially for food products. In terms of producers, an effective and efficient marketing system is one of the factors driving agricultural production. A neglected marketing system will reduce producers desire to increase production because the increase in producers income depends on the improvement of the marketing system (Anindita and Baladina, 2017).

\section{CONCLUSIONS}

The analysis of alternative marketing channel with the highest value is occupied by 'individual customers' (displays) at the producers of "One STOP Hydroponics", both of which are occupied by 'restaurants' at the same producer, "One STOP Hydroponics". The third is occupied by "kale supplier' at "JawaRa Farm". Consumer analysis of the highest trust and commitment achieved trading information and benefits of the same value to the producers of "One STOP Hydroponics".

\section{ACKNOWLEDGMENT}

We thank the "Kebunsayur Surabaya", "JawaRa Farm" and "One STOP Hydroponics" in Surabaya, Indonesia, for the provision of data and support during the data collection process.

\section{REFERENCES}

Abubakar, I., Hakim, D. B., \& Asmarantaka, R. W., (2017). Struktur, perilaku dan kinerja pemasaran biji kakao di Kabupaten Parigi Moutong Provinsi Sulawesi Tengah. Forum Agribisnis (Agribusiness Forum), 6(1), 1-20. https://doi.org/10.29244/fagb.6.1.1-20

Aji, J. M. M. (2016). Exploring farmer-supplier relationships in the East Java seed potato market. Agriculture and Agricultural Science Procedia, 9, 83-94. https://doi.org/10.1016/ j.aaspro.2016.02.130

Anindita, R., \& Baladina, N. (2017). Pemasaran produk pertanian. Yogyakarta: Andi

Aziz, M. T., \& Noor, N. A. M. (2013). Evaluating the effect of cost related factors on relationship quality. International Journal of Retail and Distribution Management, 41(7), 545-58. http://dx.doi.org/10.1108/IJRDM-05-2013-00 98

Batt, P. J. (2000). Modelling buyer-seller relationships in agribusiness in South East Asia. 16th Annual IMP Conference, 1-28. Retrieved from https://espace.curtin.edu.au/ handle/20.500.11937/8110

Batt, P. J., \& Wilson, H. (2001). Exploring the nature of long-term buyer-seller relationships in the Western Australian wine industry. Australia New Zealand Wine Industry Journal, 16(6), 87-96. Retrieved from https://espace. curtin.edu.au/bitstream/handle/20.500.11937/ 25588/169751_43288_11093.pdf?sequence $=2$

de Mooij, M. (2019). Customer behavior and culture: consequences for global marketing and advertising. 3rd Edition. SAGE Publications, Inc. Retrieved from https:// books.google.co.id/books?hl=id\&lr=\&id=DO qaDwAAQBAJ\&oi=fnd $\& p g=P P 1 \& d q=$ consu mer+behavior+theory\&ots $=\mathrm{aSwLvmtMgo \& si}$ $\mathrm{g}=\mathrm{EYFCDQSxotgHy} 7$ t66ecdov3Vxws\&redir _esc $=\mathrm{y} \# \mathrm{v}=$ onepage $\& \mathrm{q}=$ consumer $\% 20$ behavio $\mathrm{r} \% 20$ theory\& $\mathrm{f}=$ false

Dwyer, F. R., Schurr, P. H., \& Oh, S. (1987). Buyer-seller developing relationships. Journal of Marketing, 51(2), 11-27. https://doi.org/ $10.1177 / 002224298705100202$

Erzal, M. F. (2016). Analisis saluran, margin dan efisiensi pemasaran itik lokal pedaging. 
Students e-Journal, 5(1), 1-12. Retrieved from http://jurnal.unpad.ac.id/ejournal/article/view/ 8083

Febrianti, T., Tsani, A., \& Milla, A. N. (2019). Analisis preferensi konsumen terhadap sayuran hidroponik di Kota Sukabumi. Paspalum : Jurnal Ilmiah Pertanian, 7(1), 1 -8. http://dx.doi.org/10.35138/paspalum.v7i1. 85

Harahap, D. A. (2015). Analisis faktor-faktor yang mempengaruhi keputusan pembelian konsumen di pajak USU (PAJUS) Medan. Jurnal Keuangan Dan Bisnis, 7(3), 227-242. https://doi.org/10.31227/osf.io/2dg3q

Hartmann, M., Frohberg, K., \& Fischer, C. (2010). Building sustainable relationships in agri-food chains: Challenges from farm to retail. In Agri-food Chain Relationships, 25 44. Wallingford: CAB International. http:// dx.doi.org/10.1079/9781845936426.0025

Ismail, S. T. (2009). The effects of relationship marketing on organizational outcomes "An applied study in Jordanian insurance companies". European Journal of Social Sciences, 12(2), 176-184. Retrieved from http://www.kau.edu.sa/GetFile.aspx?id=2131 45\&fn=R-Ship\%20MKG,\%20Vol\%2012,\% 20Issue\%202..pdf

Jiwa, I. D. N. A. (2018). Relationship marketing, power dan loyalitas pada hubungan bisnis antara pemasok dengan peritel. Jurnal Mitra Manajemen, 2(3), 146-159. Retrieved from http://e-jurnalmitramanajemen.com/index.php /jmm/article/view/84

Johnson, G., Weinberger, K., \& Wu, M. H. (2008). The vegetable industry in tropical Asia an overview of production and trade, with a focus on Thailand, Indonesia, the Philippines, Vietnam, and India. Shanhua, Taiwan: AVRDC - The World Vegetable Center. Retrieved from https://www.research gate.net/profile/Greg_Johnson2/publication/3 06080084_The_Vegetable_Sector_in_Tropica 1_Asia_Vietnam/links/57ae6e8608ae $15 \mathrm{c} 76 \mathrm{cb}$ 397b1/The-Vegetable-Sector-in-Tropical-Asi a-Vietnam.pdf

Khuong, M. N., \& Duyen, H. T. M. (2016). Personal factors affecting consumer purchase decision towards men skin care products - A study in Ho Chi Minh City, Vietnam. International Journal of Trade, Economics and Finance, 7(2), 44-50. https:// doi.org/10.18178/ijtef.2016.7.2.497

Kumar, R. R., \& Cho, J. Y. (2014). Reuse of hydroponic waste solution. Environmental Science and Pollution Research, 21, 95699577. https://doi.org/10.1007/s11356-014-302 4-3

Levy, M., Weitz, B. A., \& Grewal, D. (2013). Retailing management. 9th ed. McGraw-Hill Education

Mariyono, J. (2019). Stepping up to market participation of smallholder agriculture in rural areas of Indonesia. Agricultural Finance Review, 79(2), 255-270. https://doi.org/ 10.1108/AFR-04-2018-0031

Masuku, M. B., \& Kirsten, J. F. (2010). The role of trust in the performance of supply chains: A Dyad analysis of smallholder farmers and processing firms in the sugar industry in Swaziland. Agrekon, Agricultural Economics Research, Policy and Practice in Southern Africa, 43(2), 147-161. https://doi.org/10.10 80/03031853.2004.9523642

Mawardati. (2018). Selection of fresh fruit bunch marketing channel in smallholder oil palm plantation in Aceh Province. Jurnal Aplikasi Manajemen, 16(2), 246-254. http://dx.doi. org/10.21776/ub.jam.2018.016.02.07

Morgan, R. M., \& Hunt, S. D. (2012). The comitment-trust teory of relationship marketing. Journal of Marketing, 58(3), 2038. https://doi.org/10.2307/1252308

Oelviani, R. (2013). Penerapan metode analytic hierarchy process untuk merumuskan strategi penguatan kinerja sistem agribisnis cabai merah di Kabupaten Temanggung. Informatika Pertanian, 27(2), 11-20. http://dx. doi.org/10.21082/ip.v22n1.2013.p11-19

Roberts-Lombard, M., Mpinganjira, M., \& Svensson, G. (2017). Antecedents and outcomes of satisfaction in buyer-supplier relationships in South Africa: A replication study. South African Journal of Economic and Management Sciences, 20(1), 1-14. https:// doi.org/10.4102/sajems.v20i1.1497 
Rudiyanto, A., Paramita, P. D., \& Suprijanto, A. (2018). Effect of growth opportunity, capital structure, management ownership, corporate social responsibility, to the value of the company with profitability as a moderating variable (Case study on Indonesia stock exchange cement sector period 2012-2016). Journal of Accounting, 4(4), 1-14. Retrieved from https://jurnal.unpand.ac.id/index.php/A KS/article/view/939

Sambo, P., Nicoletto, C., Giro, A., Pii, Y., Valentinuzzi, F., Mimmo, T., Lugli, P., Orzes, G., Mazzetto, F., Astolfi, S., Terzano, R., \& Cesco, S. (2019). Hydroponic solutions for soilless production systems: issues and opportunities in a smart agriculture perspective. Frontiers in Plant Science, 10, 923. https://doi.org/10.3389/fpls.2019.00923

Schulze, B., Wocken, C., \& Spiller, A. (2006). Relationship quality in agri-food chains: supplier management in the German pork and dairy sector. Journal on Chain and Network Science, 6(1), 55-68. https://doi.org/10.3920/ JCNS2006.x065

Seo, Y., Someya, Y., \& Dowaki, K. (2019). Environmental impacts and consumer preference for sustainably cultivated Japanese Mustard Spinach, Komatsuna. Journal of Environmental Management, 231, 364369. https://doi.org/10.1016/j.jenvman.2018. 10.077

Sivanandamoorthy, S. (2012). Impact of relationship marketing on customer loyalty on banking sectors. South Asian Journal of Marketing \& Management Research, 2(3), 179-191. Retrieved from https://www. researchgate.net/publication/311378115_IMP ACT_OF_RELATIONSHIP_MARKETING ON_CUSTOMER_LOYALTY_ON_BANKI NG_SECTORS

Srimanee, Y., \& Routray, J. K. (2012). The fruit and vegetable marketing chains in Thailand: policy impacts and implications. International Journal of Retail \& Distribution Management, 40(9), 656-675. https://doi.org/10.1108/0959 0551211255956

Swasta, B., \& Handoko, T. H. (2000). Manajemen pemasaran. 1st ed. Yogyakarta: BPFE: Yogyakarta

Syaifullah, H., \& Syairudin, B. (2016). Identifikasi perumusan strategi pada pengembangan usaha budidaya sayur hidroponik (Studi kasus: Kebunsayur Surabaya). Prosiding Seminar Nasional Manajemen Teknologi, 25, 1-8. Retrieved from https://mmt.its.ac.id/publikasi/identifika si-perumusan-strategi-pada-pengembangan-us aha-budidaya-sayur-hidroponik-studi-kasus-k ebunsayur-surabaya/

Ulfa, A. N., \& Masyhuri. (2018). Rice marketing efficiency in Sragen Regency. Agro Ekonomi, 29(2), 287-298. https://doi.org/10.22146/ae. 36442

Ulfah, Y. F. (2017). Analisis strategi pemasaran produk teh hijau celup cap dua petani (Studi kasus di Gapoktan Karya Mandiri Sejahtera, Desa Cibodas, Kecamatan Pasir Jambu, Kabupaten Bandung, Provinsi Jawa Barat). Jurnal Manajemen Dan Bisnis (Performa), 14(2), 198-211. https://doi.org/10.29313/ performa.v0i2.3629

Widyastuti, P. (2017). Enhancing competitiveness business strategy of organic vegetables using analytical hierarchy process (AHP). DeReMa Jurnal Manajemen Development Research of Management, 12(2), 256-268. http://dx.doi. org/10.19166/derema.v12i2.493

Yasmin, T. R., Prastiwi, W. D., \& Handayani, M. (2017). Analisis konjoin preferensi konsumen sayuran hidroponik Agrofarm Bandungan Kabupaten Semarang. Agrisocionomics: Jurnal Sosial Ekonomi dan Kebijakan Pertanian, 1(1), 85-93. https://dx.doi.org/ 10.14710/agrisocionomics.v1i1.1643 